\title{
THE TREND OF CHILDREN MORTALITY RATE IN INDONESIA
}

\author{
Sani Rachman Soleman \\ Department of Public Health, Faculty of Medicine, Universitas Islam Indonesia
}

\begin{abstract}
Children mortality rates describe the health services' quality as indicators of each countries' welfare, particularly in Indonesia. Several factors were determined as the main contributors of mortality, such as neonatal factors, maternal, environment and health services. The important of this research is to give recommendation to the government of Indonesia to propose some policies in handling of the increasing children mortality and intervention underlying disease as contributor mortality among children in Indonesia. The objective of this study is to describe trend and main causes of children mortality in Indonesia from 2000 to 2017. The design of this study is cross sectional. The data was taken from World Health Organization Maternal Child Epidemiology Estimation from 2000 to 2017. There were three main categories : neonatal mortality rate (NND), post neonatal mortality rate (PND) and under five mortality rate (UFIVE). The leading causes of mortality were searched according to those categories and followed by descriptive analysis by line graphs. According to the data that had been found, there was declining on NND (102.700 to 60.986), PND (138.553 to 63.471), UFIVE (241.253 to 124.457). The children mortality tend to decline at the range of 17 years, meanwhile the highest mortality among the three of groups are : premature birth in neonates, ARI in post neonates and premature birth in under five children. In conclusion, the trend of three parameters of children mortality declined within 17 years. On several cases, there were outbreak of injury on 2004 and fluctuation of measles incident among infant and under five children. Premature birth and ARI have the highest prevalence among children in Indonesia.
\end{abstract}

Keyword: Neonatal, post neonatal, under five, children mortality, Indonesia

\begin{abstract}
Angka kematian anak menggambarkan kualitas pelayanan kesehatan sebagai indikator kesejahteraan negara khususnya di Indonesia. Beberapa faktor yang berperan sebagai penyebab utama kematian adalah faktor neonatus, ibu hamil, lingkungan dan pelayanan kesehatan. Kepentingan penelitian ini adalah untuk memberikan rekomendasi kepada pemerintah Indonesia untuk mendorong kebijakan dalam pengendalian peningkatan kematian anak dan melakukan intervensi penyakit sebagai penyebab utama kematian anak di Indonesia. Tujuan dari penelitian ini adalah untuk menggambarkan tren dan penyebab utama kematian anak di Indonesia dari tahun 2000 hingga 2017. Rancangan penelitian ini adalah potong lintang. Data penelitian di ambil dari World Health Organization Maternal Child Epidemiology Estimation from 2000 to 2017. Terdapat tiga kategori utama seperti angka kematian neonatus, angka kematian pasca neonatus dan angka kematian anak dibawah lima tahun. Penyebab kematian anak dicari berdasarkan kategori tersebut dan diikuti dengan analisis secara deskriptif dengan menggunakan grafik garis. Berdasarkan data yang didapat, terdapat penurunan angka kematian neonatus (102.700 to 60.986), pasca neonatus (138.553 to 63.471) dan usia kurang dari 5 tahun ( 241.253 to 124.457 ). Angka kematian anak cenderung menurun selama 17 tahun sementara itu angka kematian tertinggi setiap group adalah kelahiran prematur pada neonatus, infeksi saluran pernapasan atas pada pasca neonatus dan kelahiran premature pada usia dibawah lima tahun. Berdasarkan hasil tersebut menunjukkan bahwa terjadi penuruan angka kematian anak selama 17 tahun, pada beberapa kasus terjadi kejadian luar biasa cedera di tahun 2004 dan fluktuasi kasus campak pada bayi dan dibawah lima tahun, sementara itu kelahiran prematur dan infeksi saluran pernapasan memiliki prevalensi paling tinggi diatara anak-anak di Indonesia.
\end{abstract}

Kata kunci: Neonatus, pasca neonatus, dibawha lima tahun, kematian anak, Indonesia. 


\section{INTRODUCTION}

Sustainable development goals consist of 17 components, one of them concerning good health and well-being ${ }^{1}$. Those concepts have specific target, that is to end the entire preventable deaths under five years of age by the end of $2030 .{ }^{1}$ In order to reach the target of ending the preventable deaths of newborns and children under five years old, all countries are aiming to decrease neonatal mortality to at least as low as 12 per 1000 live births and 25 per 1000 live births for under five mortality rate. ${ }^{2}$ Children mortality rate is significant on tracking the progress towards child survival goals as well as planning national and global health strategies, policies and interventions on child health and well-being ${ }^{2}$. Millennium Development Goals (MDG's) had made progress in reducing children mortality rate worldwide for the last 25 years. However, the progress is still insufficient regarding the target achievement of MDG's. ${ }^{3}$

Children mortality measurement consists of neonatal death (NND), post neonatal death (PND) and under five death (UFIVE). Globally, NND had declined from 35 deaths per 1000 live births on 1990 to 19 deaths per 1000 live births on 2015, the number of death declined from 5.1 millions to 2.7 millions. ${ }^{4}$ The global data of UFIVE had declined as much as $53 \%$, from 91 deaths per 1000 live births to 5.9 deaths per 1000 live birth, the number of UFIVE had dropped from 12.7 million in 1990 to 5.9 millions in $2015 .^{2}$ The condition of children mortality itself is complex among WHO's regional countries, furthermore Sub Sahara Africa region is more affected than others. ${ }^{2,4}$ Meanwhile in Southeastern Asia, there was a significant decline as much as $52 \%$, from 28 to 12 per 1000 live births. ${ }^{4}$ In Indonesia according to Indonesian Demographic and Health Survey (IDHS) between 1991 to 2012 the children mortality rate is divided into three parameters : neonatal mortality, infant mortality and under five mortality. ${ }^{5}$ The data showed the highest rate of children mortality in Indonesia on 1991, which is approximately 32 per 1000 live birth and the lowest rate within 2007 and 2012 which is approximately 19 per 1000 live birth. ${ }^{2,5}$ Infant mortality in Indonesia showed the highest prevalence of 68 per 1000 live births on 1991 and the lowest rate of 32 per 1000 live births on 2012.4.5 Under five mortality illustrated the highest mortality rate of 97 per 1000 live birth in 1991 and the lowest rate of 40 per 1000 live births in $2012 .^{5}$

On most developing countries, children mortality is caused by complex etiologies such as premature birth, asphyxia, sepsis, injury, measles, respiratory infection and congenital. ${ }^{6}$ It is crucial, that most of the children deaths are caused by maternal factors that actually could be prevented and fixed during pregnancy such infections that can be transmitted via intrauterine pathway into fetus blood circulations. ${ }^{7,8}$ The most frequent case that is neonatal asphyxia, could be prevented by appropriate ante and intrapartum care, particularly if the mother has underlying diseases that should 
be considerate for appropriate treatment. ${ }^{9,10}$ The suitable approach, management and intervention on pregnant women could reduce the negative outcome of pregnancy, as well as the health of the mother and baby. Infection is still an appalling risk factors of death among children, particularly acute respiratory infection (ARI). ${ }^{11}$ Acute respiratory infection itself divided into two groups, upper respiratory infection (URI) and lower respiratory infection (LRI), both affect under five children. Under five children have two or three times higher ARI incidents than another ages group. This could be triggered by socioeconomic factors, inadequate nutrition and incomplete vaccination. ${ }^{12}$ The other leading causes of mortality beside that are premature birth, congenital malformations, diarrhea, injury and measles. Accumulation of those factors plays important role on prevalence and incidence of children mortality rate, particularly under five.

According to explanation above, this study will give input and recommendation to government of Indonesia to handle leading causes of children mortality. The government should concern how to manage premature birth and ARI that can be prevented with appropriate management and supporting policies by governments. According to explanation above, the objective of this study is to describe trend and main causes of children mortality in Indonesia from 2000 to 2017 . This study is a pivotal to take action in handling children mortality based on the trend and predicting cause of mortality in the future to mitigate the health impact for children.

\section{METHOD}

A cross-sectional study is used to analyze the data NND, PND and UFIVE that taken from World Health Organization Maternal Child Epidemiology Estimation (WHO MCEE) for the causes of neonatal death database from 2000 to 2017 in Indonesia. The data WHO MCEE provide information of cause death among WHO six regional such as Africa, America, South East Asia, Europe, Eastern Mediterranean and Western Pacific. Meanwhile the cause of death data divided into 14 categories : HIV/AIDS, diarrhea, tetanus, measles, meningitis/encephalitis, malaria, acute respiratory infections, premature birth, birth asphyxia and birth trauma, sepsis and another newborn infections, congenital defects, non-communicable diseases and injuries. In this study, the data was taken in Indonesia during 2000 to 2017, however the cause of death was taken based on the most prevalence mortality in every step of growth such as NND, PND and UFIVE. The data of children mortality was analyzed and compared with NND, PND and UFIVE to describe the trends from 2000 to 2017. Ethical clearance was not proposed by the author because WHO MCEE data was open source data that could be accessed by everyone. 


\section{RESULT}

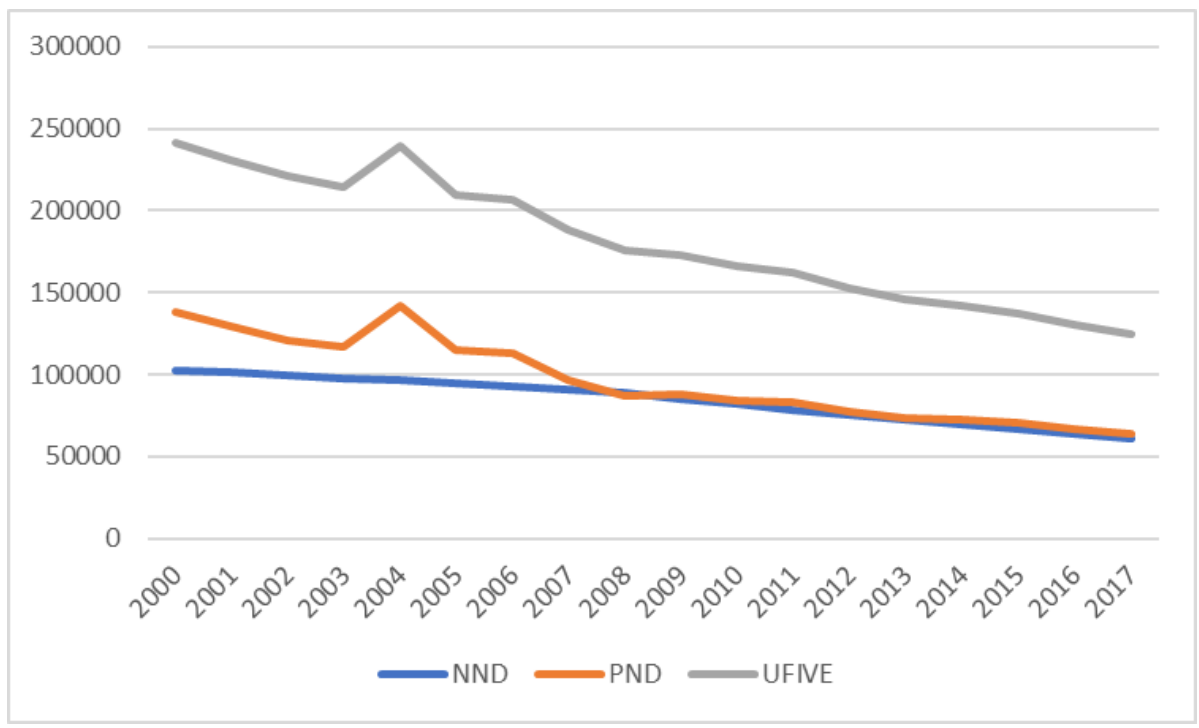

Figure 1. The trend of neonatal mortality death (nnd), post neonatal mortality death (pnd) and under five mortality death (ufive) in indonesia from 200 to 2017.

The figure one illustrated the declining of NND, PND and UFIVE by 17 years. From the diagram, we could clearly see that the mortality of UFIVE was the most dominant, followed by PND and NND. The number of UFIVE in 2000 at 241.253 and by the end of 2017, decreased up to 124.457. Meanwhile the trend of PND dropped from 138.553 at the beginning of 2000 to 63.471 by the end of 2017. Interestingly, in 2004-2005, on both UFIVE and PND, there were increasing number of death, that is 239.375 and 142.441 respectively. On the other hand, the trend of NND is continually decreased from 102.700 in 2000 to 60.986 in 2017.

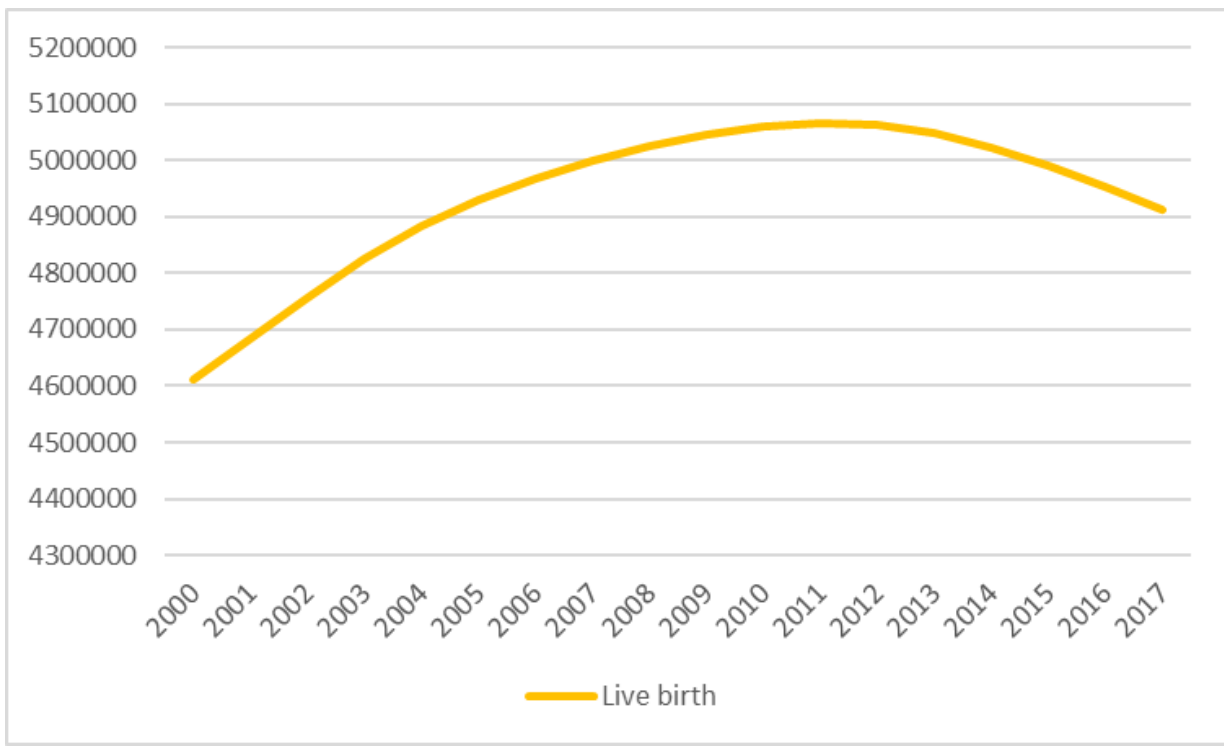


Figure 2. The trend of live birth in Indonesia from 2000 to 2017

Figure two concluded the tendency of live birth in Indonesia. From 2000 to 2017 there was 4.611.047 in 2000 and by the end of 2017 there was 4.912.756. The trend of live birth in Indonesia is fluctuated, and reached its highest number that is 5.067.185 in 2011.

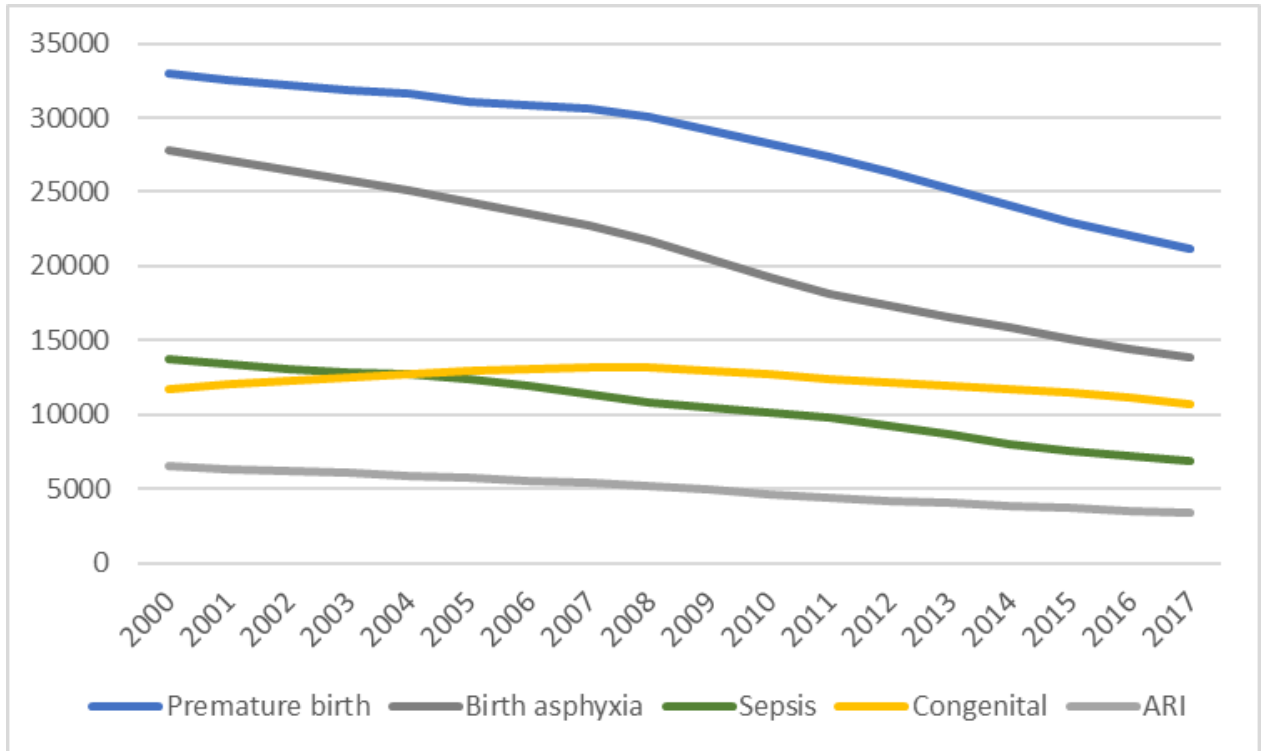

Figure 3. The trend of causes NND in Indonesia from 2000 to 2017

Figure three showed that premature birth was the most leading cause of NND (32.953 in 2000 to 21.147 in 2017) followed by birth asphyxia (27.794 in 2000 to 13.843 in 2017), congenital disorder (11.740 in 2000 to 10.702 in 2017), sepsis (13.775 in 2000 to 6.914 in 2017) and ARI (6.514 in 2000 to 3.362 in 2017). From the diagram, it could be concluded that there was a declining on the leading causes of NND, besides congenital that overcame sepsis in 2004 and reaching the highest number of 13.204 in 2007.

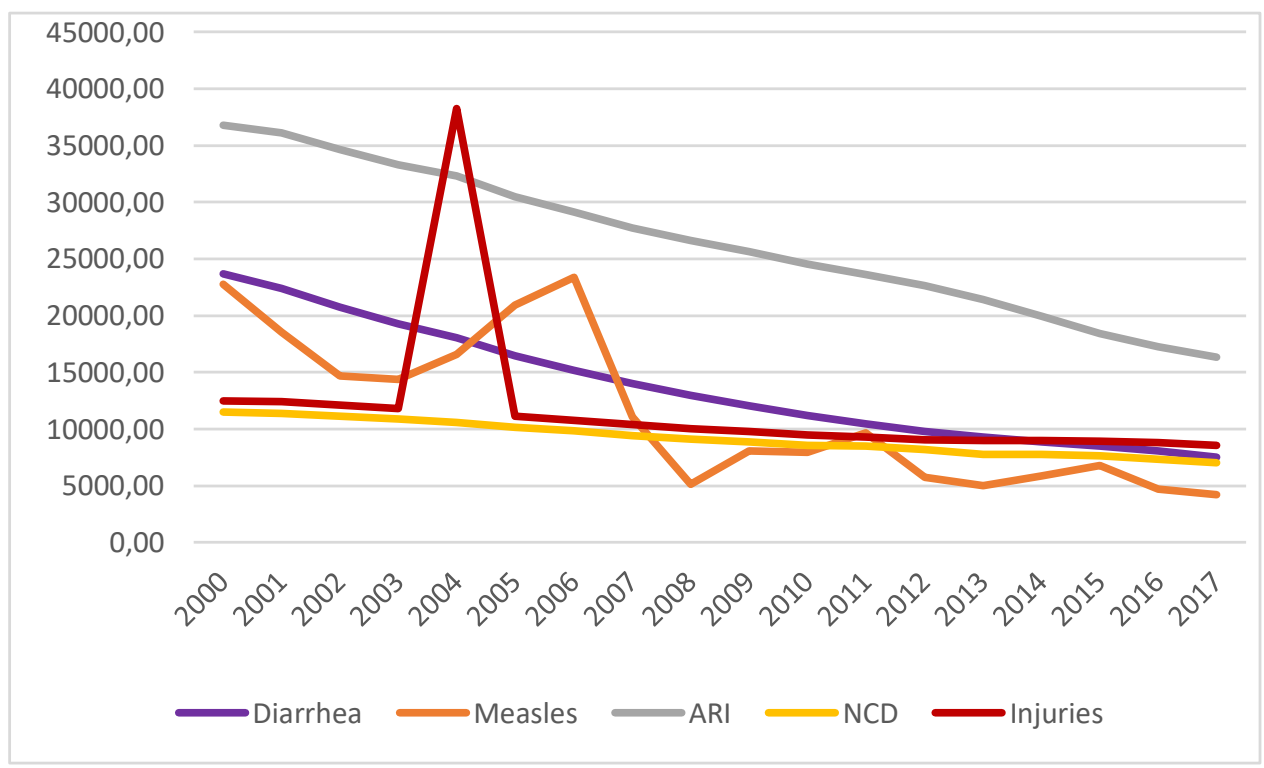




\section{Figure 4. The trend of causes PND in Indonesia from 2000 to 2017}

Figure four explained ARI as the highest cause of PND in Indonesia (36.771 in 2000 to 16.310 in 2017), followed by injury (12.462 in 2000 to 8.579 in 2017), diarrhea (23.666 in 2000 to 7.542 in 2017), Non communicable diseases (NCD) (11.472 in 2000 to 7.058 in 2017) and measles (22.750 in 2000 to 4.194 in 2017). From the diagram, it could be concluded that there was a decline on all leading causes of PND, however there was a significant increasing number of injury in 2004 of 38.272 and fluctuation of measles for 17 years that reached the highest number in 2004, roughly 23.396 and creating fluctuated pattern in 2000, 2006, 2011 and 2015.

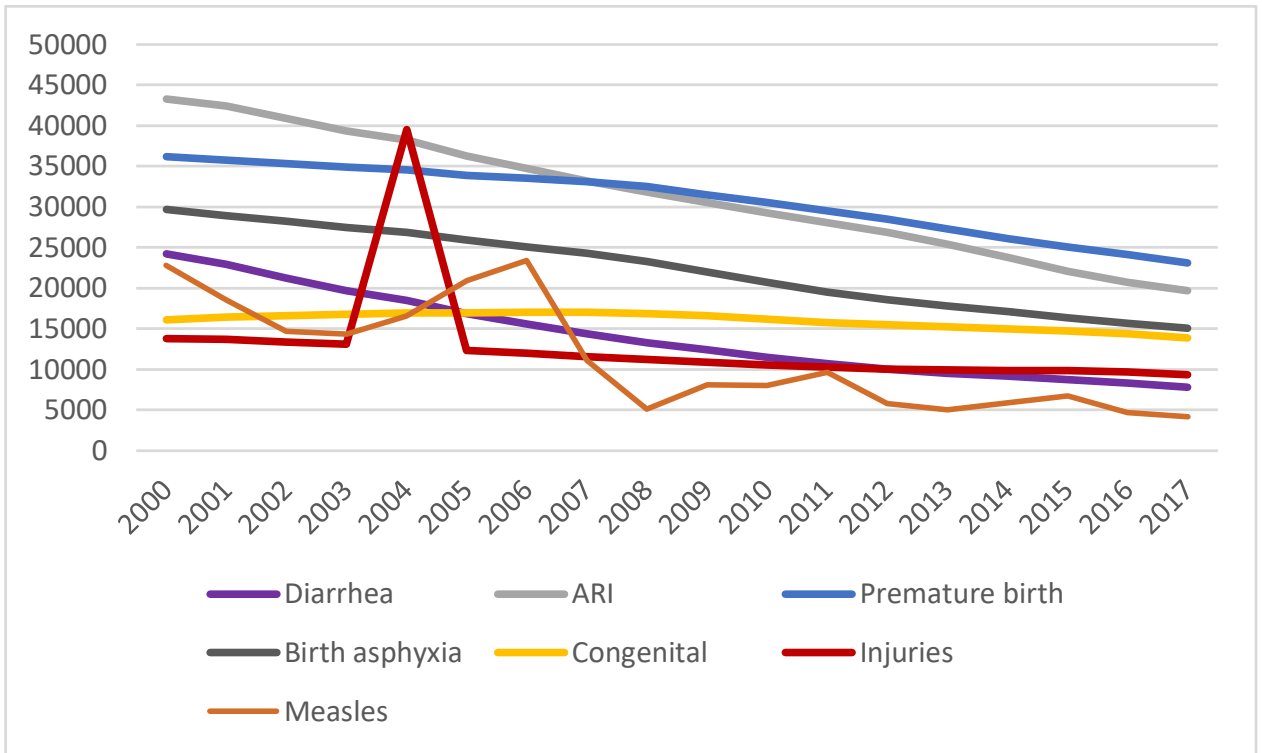

Figure 5. The trend of UFIVE in Indonesia from 2000 to 2017

According to figure five,the preterm birth was still the most dominant of UFIVE (36.200 in 2000 to 23.090 in 2017) followed by ARI (43.285 in 2000 to 19.672 in 2017), birth asphyxia (29.632 in 2000 to 15.034 in 2017), congenital (16.117 in 2000 to 13.818 in 2017), injury (13.770 in 2000 to 9.368 in 2017), diarrhea (24.190 in 2000 to 7.750 in 2017) and measles (22.750 in 2000 to 4.194 in 2017). From the diagram, it could be concluded that there was decreasing number between the leading causes UFIVE in Indonesia, however the trend of injury was significantly increased in 2004, around 39.510 and the tendency of measles fluctuated which was getting the highest number around 23.396 in 2006 and creating fluctuation pattern such PND.

\section{DISCUSSION}

Children mortality rate in Indonesia declined significantly due to implementation of health program in Indonesia such as family planning implementation, strengthening community health services center (PUSKESMAS), emergency on obstetric and newborn care implementation and community health insurance (Jamkesmas) that was established in 2004 by the Ministry of Health 
(MoH). ${ }^{13,14}$ The policy was strengthened by the insurance of birth delivery (Jampersal) in the next year to support maternal health policy in Indonesia. ${ }^{15}$ Furthermore, mandatory immunization forced by government aim to prevent communicable disease among infants. ${ }^{16}$ The commitment of $\mathrm{MoH}$ to support on health policy in Indonesia was proved by increasing of budget allocation for health every year. The innovation program such as promotion of healthy and clean behaviour, tuberculosis eradicating program and community health movement (GERMAS) were established to assist maternal and children well being. ${ }^{17,18}$ Particularly in community health services (puskesmas), the $\mathrm{MoH}$ urged the strengthening of primary care as a gate keeper in community, beside the innovation program in puskesmas that was comprehensively integrated into some programs such as increasing target of minimum services standard (SPM) and implementation of Indonesia health program and family education (PIS-PK). ${ }^{19}$

Neonatal mortality in Indonesia was contributed by several factors such as premature birth, asphyxia, sepsis, congenital and ARI. Almost the cause of preterm birth and birth asphyxia in Indonesia are singleton pregnancy and head presentation, ante partum bleeding, premature birth, preeclampsia, post mature and cesarean delivery. ${ }^{20}$ This is interesting that the trend for those factors (premature birth and birth asphyxia) started to decline along with the implementation of community health insurance (JAMKESMAS) that had been implemented since 2005. However, congenital disorder prevalence is still stagnant. There are several anomalies that could be identified as failure of fetus or embryo development process during pregnancy, these term including structural, functional, metabolic and hereditary conditions. ${ }^{21}$ According to the data from UNICEF in 2015, congenital defect was on the third place of mortality rate beside premature birth (35.5\%), asphyxia and birth trauma (21.6\%) and congenital malformations (17.1\%). ${ }^{22}$ According to survey by $\mathrm{MoH}$ from 2014 to 2018 , the trend of congenital disorders in Indonesia are : equinovarus (21.9\%), orofacial cleft (20.4\%), neural tube defects (18.4\%), abdominal wall defects (16.4\%), atresia ani (9.7\%), hypospadias $(4.8 \%)$, conjoined $(4.2 \%)$ and microcephaly $(2.3 \%) .{ }^{23}$ Those anomalies were stimulated by genetic factors, social-economic, nutrition status and environmental.

Post neonatal death in Indonesia was affected by several factors such as neonatal factors, maternal, social-demographic and health services. ${ }^{24}$ The trend of PND was declining for entire leading causes as well as ARI, diarrhea, measles, non communicable diseases and injury. According to the data, the increasing injury prevalence in 2004 is due to the magnificent earthquake that struck Aceh province in 2004, that leads to Tsunami that destroyed the coastal regions in Aceh. More than 100.000 people died, most of them were elderly and young people. The mortality rate was dominated by children 0-9 years old, on all the four biggest districts in Aceh, West Coast (29\%), Banda Aceh (30\%), Meulaboh (21\%) and East Cost $(9 \%) .{ }^{25}$ The other leading cause is measles that showed fluctuation trend each year. The government of Indonesia urges some programs to eliminate measles and rubella (MR), especially on children aged 9 month to 15 years old, through immunizations. ${ }^{26}$ 
However, the struggle to implement these programs are still stagnant due to massive anti vaccination campaign. This campaign was still very influencing, despite moslem religious leaders who accepted vaccination program to prevent children from serious illness. ${ }^{27,28}$

Under five mortality death in Indonesia was influenced by some factors such as ARI, diarrhea, congenital malformations, birth asphyxia, measles, premature birth and injury. The trend of UFIVE in Indonesia was declined due to successful program on strengthening primary care. Nevertheless, injury among UFIVE was still increasing in 2004 because of the devastating earthquake and Tsunami in Aceh province. ${ }^{25}$ Thousands of people were displaced, most of them were children and elderly. The situation of measles, as the leading cause of death, was still fluctuated as result of huge campaign of anti vaccination movement despite community leaders approved that vaccination is approved by the Holy Koran and Prophet Muhammad aforementioned. ${ }^{29}$ According to data, premature birth in 2007 overcame the ARI. The prevalence of preterm birth among under five children is influenced by age, demographic and socioeconomic factors particularly in poor regions. ${ }^{30,31}$ Most of under five children who suffered preterm birth in neonates phase carried co-morbid factors and complication that increased the morbidity and mortality on under five period.

This study has limitation on research of methodology. The descriptive method can not explain the correlation between leading causes of children mortality yet further research could be proposed with cohort or mix method study to search significantly correlation between variables.

\section{CONCLUSION}

In conclusion, the trend of NND, PND and UFIVE decreased within 17 years. On several cases of NND was caused by premature birth, asphyxia, sepsis, congenital and ARI meanwhile PND was induced by diarrhea, measles, ARI, NCD and injury. Lastly, UFIVE was generated by premature birth, ARI, birth asphyxia, congenital and injury. Overall, premature baby and infections were the most dominants cases among children mortality rate in Indonesia. This paper endorse government to formulate policies and community empowerment programs to those leading causes of mortality that can be prevented with appropriate approaches.

\section{REFERENCES}

1. United Nations. The Sustainable Development Goals Report. 2019. Available from: https://unstats.un.org [Accessed 21 August 2019]

2. United Nations. Special edition: progress towards the Sustainable Development Goals. Vol. 07404. 2019. Available from: https://undocs.org [Accessed 21 August 2019]

3. United Nations. The Millennium Development Goals Report 2015. 2015. Available from: https://www.un.org/millenniumgoals/2015_MDG_Report/pdf/MDG 2015 rev (July 1).pdf. [Accessed 21 August 2019] 
4. Hug L, Alexander M, You D, Alkema L. National, regional, and global levels and trends in neonatal mortality between 1990 and 2017, with scenario-based projections to 2030: a systematic analysis. Lancet Glob Heal 2019;7(6):e710-20.

5. Ministry of Health. Indonesia Demographic and Health Survey Adolescent Reproductive Health.2013.Available from https://kesga.kemkes.go.id [Accessed 21 August 2019]

6. Abdullah A, Hort K, Butu Y, Simpson L. Risk factors associated with neonatal deaths: a matched case control study in Indonesia. Glob Health Action 2016;9:1-12.

7. Maniruzzaman M, Nishith K, Harman S, Menhazul A. Risk factors of neonatal mortality and child mortality in Bangladesh. J Glob Health 2018;8(1):1-17.

8. Theoneste N. Maternal and Newborn Risk Factors associated with neonatal mortality in Gitwe District Hospital in Ruhango District , Rwanda. Int J Med Pubic Heal 2016;6(2):98102.

9. Suparmi S, Chiera B, Pradono J. Low birth weights and risk of neonatal mortality in Indonesia. Heal Sci J Indones 2017;7(December):1-6.

10. Lee A, Mullany C, Tielsch M, Katz J, Kharty S, LeClerq S, Adhikari R, Shrestha S, Darmstadt G. Risk factors for neonatal mortality due to birth asphyxia in Southern Nepal: A prosperctive, Community-based Cohort Study. Pediatrics 2009;121(5):1-18.

11. Chen J, Hu P, Zhou T, Zheng T, Zhou L, Jiang C, Pei X. Epidemiology and clinical characteristics of acute respiratory tract infections among hospitalized infants and young children in Chengdu, West china, 2009-2014. BMC Pediatr 2018;18(216):1-8.

12. Caballero MT, Bianchi AM, Nuño A, Ferretti A, Polack L, Remondino I, Rodrigue M, Orizzonte L, Vallone F, Bergel E, Polack F. Mortality associated with acute respiratory infections among children at home. J Infect Dis 2019;219:358-64.

13. Vice President Republic Indonesia. The Road to National Health Insurance ( JKN ). Office of Vice President Republic of Indonesia; 2012. Available from: http://www.tnp2k.go.id/ [Accessed 21 August 2019]

14. The National Academies. Reducing maternal and neonatal mortality in Indonesia: saving lives, saving the future affairs ; National Research Council ; Indonesian Academy of Sciences Joint Committee on Reducing Maternal and Neonatal Mortality in Indonesia Development,Security,2013.Availablefrom:https://www.ncbi.nlm.nih.gov/books/NBK2017 07/[Accessed 21 August 2019]

15. Handayani L, Suharmiati S, Kurniawan A, Nuraini S, Rahanto S. Utilization of service delivery insurance (Jampersal) for maternal and child health services in 12 Districts/Cities: eliminate the socio-cultural obstacle on safe delivery. Bul Penelit Sist Kesehat 2013;16(4):419-27.

16. Yosephine P. Indonesia National Immunization Program : In: 3rd International Symposium 
for Asia Pacific Experts. Hanoi Vietnam; 2017. Available from: https://www.fondationmerieux.org [Accessed 21 August 2019]

17. Gisely V, Kusumaningtiar DA. Knowledge of Clean and Healthy Behavior and Quality of Life among School-Children. Adv Heal Sci Res 2017;2:1-8

18. Ministry of Health Republic Indonesia. Current status of integrated community based TB service delivery and the Global Fund work plan to find missing TB cases 2018. https://www.who.it [Accessed 21 August 2019]

19. Anita B, Febriawati H, Yandrizal. The role of public health centers (puskesmas) as the gatekeeper of national health insurance. J Kesehat Masy. 2016;12(2014):76-89.

20. Sungkar A, Fattah A, Surya R, Santoso B, Zalud I. High preterm birth at Cipto Mangunkusumo Hospital as a national referral hospital in Indonesia. Med J Indones 2017;26(3):198-203.

21. Firth C, Petherick E, Oddie S. Infant deaths from congenital anomalies : novel use of Child Death Overview Panel data. Arch Dis Child 2018;0:1-6.

22. UNICEF. Maternal and Newborn Health Disparities. UNICEF; 2016. https://data.unicef.org [Accessed 28 August 2019]

23. Kementrian Kesehatan. Kelainan Bawaan. 2018.https://depkes.go.id>download>infodatinkelainan-bawaan.pdf [Accessed 28 August 2019]

24. Sari IP, Ardillah Y, Widyastuti TA. The determinants of infant mortality in neonatal period. J Kesehat Masy 2016;12(1):139-49.

25. Doocy S, Daniel A, Dick A, Kirsch T. The human impact of tsunamis : a historical review of events 1900-2009 and systematic literature review. PLOS Curr Disasters 2013;(April):1-20.

26. Grubb B. UNICEF support to the govt of Indonesia measles-rubella campaign 2017-2018 most of world 's poor live in middle-income countries. 2018. https://www.unescap.org > sites > default > files > UNICEF support to the Govt of Indonesia Measles-Rubella Campaign 20172018. pdf [Accessed 10 September 2019]

27. Hussain A, Ali S, Ahmed M, Hussain S. The anti-vaccination movement : a regression in modern medicine origins of the anti-vaccination movement. Cureus 2018;10(7):1-8.

28. Padmawati RS, Heywood A, Sitaresmi MN, Atthobari J, MacIntyre C, Soenarti Y, Seale H. Religious and community leaders ' acceptance of rotavirus vaccine introduction in Yogyakarta, Indonesia : a qualitative study. BMC Public Health 2019;19(368):1-6.

29. Nuraishah E, Zainudin H, Mohammad K, Aris A, Shahdan I. Vaccination : influencing factors and view from an Islamic perspective . IMJM 2018;17(2):1-8.

30. Chao F, You D, Pedersen J, Hug L, Alkema L. National and regional under-5 mortality rate by economic status for low-income and middle-income countries : a systematic assessment. Lancet Glob Heal 2018;6(5):e535-47. 
31. Guevara I, Zuo W, Bendavid E, Li N, Tuljapurkar S. Age distribution, trends, and forecasts of under-5 mortality in 31 sub-Saharan African countries: A modeling study. PLOS Med 2019;(March):1-21. 